\title{
The Role of Gender Factor in Career Advancement of Academics
}

\author{
Dilara Ustabaşı Gündüz
}

\begin{abstract}
This study is aimed to determine academics' negative and positive perceptions of gender factor in career advancement, to identify the problems encountered and to propose solutions to these problems. Basically the situations related to the effect of gender factor in career advancement of female and male academics working at the universities in Konya, Turkey are investigated. Critical success factors, barriers to career advancement have been identified from the standpoint of female and male academics. Moreover, the satisfaction levels and female and male academics' perceptions of gender-based discrimination about the working life have been assessed. This study is based on an empirical analysis on a survey which was conducted among 34 females, 52 males, total 86 academics of 2 public and 2 foundation universities chosen by purposive sampling method. The results show that the academics in Konya have conceptions that male academics are trusted, empowered, and given responsibility/task/assignment more and male academics get higher salary then female academics at the same level. Hence, the academics in Konya have the perception of gender-based discrimination.
\end{abstract}

Index Terms-Academics, career advancement, gender-based discrimination.

\section{INTRODUCTION}

Gender inequality is one of the much-discussed social problems in history. Sex is a term used to classify the individual's physiological and biological properties. Sexism occurs at different levels from individual discrimination to institutionalized discrimination. However, the common feature found in all forms of sexism is inequality and unjust discrimination [1]. What is meant by gender is the meaning and expectations which are imposed by society to being female or being male [2]. Gender roles imposed by society of women and men often prevent women's self-realization and also affects social relations negatively.

In Turkey, as in Western countries, legal arrangements are carried out in the public domain to prevent gender based discrimination in worklife. As the fact that the realization of law as not being effective in academic are, academic studies on this subject have increased over time.

As well as the role of gender in society, there are also professions which are matched with genders by society [3]. Female's and male's way to take shape in the career advancement process are diffirent. Because the responsibilities imposed on societies to gender are able to affects women's career development negatively. Gender bias

Manuscript received October 10, 2015; revised February 10, 2016. This work was supported in part by KTO Karatay University

D. Ustabaşı Gündüz is with KTO Karatay University, Karatay, Konya, Turkey (e-mail: dilara.ustabasi @ karatay.edu.tr). is an obstacle to career development. No matter the profession, whereas women doing important studies towards career development in worklife, they have additional roles such as housewife, wife, mother, and daughter.

Women's career development is important both to be a good role model for children and educate beneficial individuals for society. Women should care her children and work at the same time. However, with all these things she has to carry away both happiness at home and success at worklife. So it is difficult to expect women's career advancement to be faster then men's [4].

Academic is a profession that forces career advancement and has sharp hierarchical steps because of its nature. Each academic has to study constantly and regularly in order to perform successful studies and advance to the next academic level. In a profession that requires studies with such care and attention, advancement of women is not easy as men's, because of responsibilities which can affect career advancement. This can be seen from the women ratio of academics in Turkey. According to the higher education statistics, there are 149,376 academics in total in Turkey. In that number, the ratios of female academics according to titles are as follows; $15.1 \%$ are research assistants, $8.9 \%$ are assistant professors, $3.3 \%$ are assoc. professor and $4.2 \%$ are professors. On the other hand, the ratios of male academics according to titles are as follows; $15.1 \%$ are research assistants, $13.5 \%$ are assistant professors, $6.2 \%$ are assoc. professor and $10.2 \%$ are professors [5]. As can be seen from the statistics the title ratios of female academics are lower than male academics.

\section{Methodology}

\section{A. Research Goal}

In this study it is aimed to determine academics' negative and positive perceptions of gender factor in career advancement in 2 public and 2 foundation universities in Konya. Problems encountered during the process of making an academic career of academics in worklife will be determined. The research questions listed below are developed in this regards:

1) Is there diffirence between female and male academics' number of scientific studies in last year?

2) Have female and male academics diffent distribution of academics studying time at home and workplace?

3) Is there diffirence between female and male academics' perception of critical success factors?

4) Is there diffirence between female and male academics' perception of barriers in career advancement? 
5) Is there diffirence between female and male academics' level of satisfaction of working life?

6) Is there diffirence between female and male academics' perception of preferation due to gender?

7) What are the academics' perceptions about the gender basis discrimination at their worklife?

\section{B. Research Model and Sample}

Due to its attributions this study includes a descriptive research. Scanning models aim to describe an existing condition by shaping the portrayal in past and current [6]. The population of study is academics working in universities in Konya. Sampling method is judgmental sampling which is a nonprobability sampling method. In judgmental sampling or purposive sampling, elements that compose sample are based on chosing from people whom researcher believes to get answer. So the criteria of determining the sample is judgment of researcher [7]. A one to one survey was conducted from a sample of 86 academics studying in different fields in 2 public and 2 foundation universities in Konya.

\section{Data Collection and Analysis}

The data in the study were collected through a survey prepared in accordance with domestic and foreign literature. In the questionnaire consisting of 33 questions, there are questions related to the subject and purpose of the study. The first nine questions of the questionnaire are about socio-demographic characteristics of respondents, and following questions are related to home and worklife which are prepared to identify success factors in career development, barriers to success and satisfaction. In the last part of the questionnaire there are questions for perceptions related to gender. Survey was carried out in one month.

The data obtained from the survey are statistically analyzed with IBM SPSS Statistics 20.0 (The Statistical Program for Social Science). Chi-square, descriptive tests and t-tests are utilized to test hypothesis.

\section{ANALYSIS AND RESULTS}

\section{A. Socio-Demographic Characteristics of the Participants}

TABLE I: SEX AND AGE DISTRIBUTION OF PARTICIPANTS

\begin{tabular}{lll}
\hline \hline Sex & Frequency & Percent \\
\hline Female & 34 & 39.5 \\
Male & 52 & 60.5 \\
Total & 86 & 100 \\
\hline Age & Frequency & Percent \\
\hline $25-30$ & 35 & 39.5 \\
$31-36$ & 15 & 17.4 \\
$37-42$ & 4 & 4.7 \\
$43-48$ & 11 & 12.8 \\
$49-54$ & 10 & 11.6 \\
$55-60$ & 4 & 4.7 \\
$61-66$ & 1 & 1.2 \\
$67+$ & 4 & 4.7 \\
Unanswered & 2 & 2.3 \\
Total & 86 & 100 \\
\hline \hline
\end{tabular}

Table I shows the age distribution of the participants. Majority respondents are aging from 25 to 30 years old
(\%40.7) ve from 31 to 36 years old (\%17.4). Table I shows that the majority of participants are young academics.

Majority of the participants have Master degree (47.7\%) and second majority of participants have PhD (44.2\%). 38.4 percent of participants are research assistants, second majority (19.8\%) are assistant professors. Lastly, $17.4 \%$ are instructers and $12,8 \%$ are professors.

TABLE II: ACCORDING TO TITLE DISTRIBUTION AND EDUCATION

\begin{tabular}{lll}
\hline \hline Education & Frequency & Percent \\
\hline Bachelor & 7 & 8.1 \\
Master & 41 & 47.7 \\
PhD & 38 & 44.2 \\
Total & 86 & 100 \\
\hline Title & Frequency & Percent \\
\hline Professor & 11 & 12.8 \\
Associate & 6 & 7.0 \\
Professor & & \\
Assistant & 17 & 19.8 \\
Professor & & 17.4 \\
Instructer & 15 & 4.7 \\
Lecturer & 4 & 38.4 \\
Research Assistant & 33 & 1.2 \\
Total & 1 & \\
\hline \hline
\end{tabular}

TABLE III: ACADEMICS' FAMILY LIFE CYCLE

\begin{tabular}{lll}
\hline \hline Marital Status & Frequency & Percent \\
\hline Single & 29 & 33.7 \\
Married & 57 & 66.3 \\
Total & 86 & 100 \\
\hline With/Without & Frequency & Percent \\
Children & & \\
\hline Have Children & 46 & 53.5 \\
Haven't Children & 40 & 46.6 \\
Total & 1 & 100 \\
\hline Spouse's Job & Frequency & Percent \\
\hline Academic & 16 & 28.1 \\
Teacher & 8 & 14.0 \\
Housewife & 5 & 8.8 \\
Retired & 3 & 5.3 \\
Engineer & 8 & 14.0 \\
Lawyer & 2 & 3.5 \\
Other & 10 & 17.5 \\
Total & 86 & 100 \\
\hline \hline
\end{tabular}

TABLE IV: SCIENTIFIC STUDIES OF ACADEMICS ACCORDING TO GENDER

\begin{tabular}{lcccccc}
\hline \hline In one year & Fre & Sex & $M$ & $S D$ & $\mathrm{t}$ & $p$ \\
\hline The number of & 34 & $\mathrm{~F}$ & 1.41 & 1.598 & -1.542 & 0.127 \\
scientific & 52 & $\mathrm{M}$ & 1.98 & 1.721 & & \\
$\begin{array}{l}\text { presentations } \\
\text { The number of }\end{array}$ & 34 & $\mathrm{~F}$ & 0.74 & 1.163 & & \\
published & 52 & $\mathrm{M}$ & 1.17 & 1.184 & -1.689 & 0.095 \\
$\begin{array}{l}\text { articles } \\
\text { Number of }\end{array}$ & 34 & $\mathrm{~F}$ & 2.00 & 1.775 & & \\
$\begin{array}{l}\text { participation } \\
\text { in scientific }\end{array}$ & 52 & $\mathrm{M}$ & 2.02 & 1.615 & & \\
meetings & & & & & & \\
\hline \hline
\end{tabular}

In the sample processed within the scope of the research discussed, $66.3 \%$ majority of academis are married and $33,7 \%$ is single. $53.5 \%$ of academics have children. $70.2 \%$ of married academics' spouse is working. $28,1 \%$ of academics have the same job with their spouse. 14 percent's spouse are teacher and again 14 percent's spouse are engineers. 


\section{B. Academics' Number of Scientific Studies and Working Hours}

In this part the results of the research question "is there diffirence between female and male academics' number of scientific studies in last year?" are tested and interpreted.

The research question above is tested with independent sample t-test as shown in Table IV. The results show that female and male academics' have the same scientific presentations, and the same scientific meeting participations in last year. Nonetheless, the scientific writing numbers of female and male academics in last year are statistically different in 0.90 confidence interval.

As can be seen from Table IV, whereas the mean of female academics' scientific writing number in last year is 0.74 , it is 1.17 for male academics. This differentiation of measure is adequate to accept that means of main population are statistically different. Hereby, the proposition of male academics in Konya region has more scientific writings than female academics is accepted.

TABLE V: WEEKLy STUDYING HOURS OF ACADEMICIANS ACCORDING TO GENDER

\begin{tabular}{lcccccl}
\hline \hline & Fre & Sex & $M$ & $S D$ & $\mathrm{t}$ & $p$ \\
\hline Giving time & 34 & $\mathrm{~F}$ & 1.26 & 0.448 & 0.100 & 0.921 \\
to study at & 52 & $\mathrm{M}$ & 1.25 & 0.440 & & \\
work & & & & & & \\
$\begin{array}{l}\text { Giving time } \\
\text { to study at }\end{array}$ & 34 & $\mathrm{~F}$ & 1.18 & 0.387 & & \\
home & 52 & $\mathrm{M}$ & 1.31 & 0.469 & -1.415 & 0.145 \\
\hline \hline
\end{tabular}

TABLE VI: CRITICAL SUCCESS FACTORS OF ACADEMICS ACCORDING TO GENDER

\begin{tabular}{|c|c|c|c|c|c|c|}
\hline Factors & Sex & Fre & $M$ & $S D$ & $\mathrm{t}$ & $p$ \\
\hline \multirow{2}{*}{ Experience } & $\mathrm{F}$ & 34 & 1.41 & 0.50 & \multirow{2}{*}{1.74} & \multirow{2}{*}{0.09} \\
\hline & $\mathrm{M}$ & 52 & 1.23 & 0.43 & & \\
\hline \multirow{2}{*}{ Gender } & $\mathrm{F}$ & 34 & 1.91 & 0.29 & \multirow{2}{*}{0.65} & \multirow{2}{*}{0.52} \\
\hline & M & 52 & 1.87 & 0.35 & & \\
\hline \multirow{2}{*}{ Education } & $\mathrm{F}$ & 34 & 1.21 & 0.41 & \multirow{2}{*}{1.62} & \multirow{2}{*}{0.11} \\
\hline & $\mathrm{M}$ & 52 & 1.08 & 0.27 & & \\
\hline \multirow{2}{*}{ Seniority } & $\mathrm{F}$ & 34 & 1.91 & 0.29 & \multirow{2}{*}{0.88} & \multirow{2}{*}{0.38} \\
\hline & $\mathrm{M}$ & 52 & 1.85 & 0.36 & & \\
\hline \multirow{2}{*}{$\begin{array}{l}\text { Interpersonal } \\
\text { skills }\end{array}$} & $\mathrm{F}$ & 34 & 1.29 & 0.46 & \multirow{2}{*}{-0.50} & \multirow{2}{*}{0.62} \\
\hline & $\mathrm{M}$ & 52 & 1.35 & 0.48 & & \\
\hline \multirow{2}{*}{$\begin{array}{l}\text { Ability in } \\
\text { Tackling } \\
\text { Management }\end{array}$} & $\mathrm{F}$ & 34 & 1.82 & 0.39 & \multirow[b]{2}{*}{-0.28} & \multirow[b]{2}{*}{0.78} \\
\hline & $\mathrm{M}$ & 52 & 1.85 & 0.36 & & \\
\hline Commitment & $\mathrm{F}$ & 34 & 1.24 & 0.43 & \multirow{2}{*}{1.39} & \multirow{2}{*}{0.17} \\
\hline \& Dedication & M & 52 & 1.12 & 0.32 & & \\
\hline \multirow{2}{*}{$\begin{array}{l}\text { Support from } \\
\text { Management } \\
\text { \& Colleagues }\end{array}$} & $\mathrm{F}$ & & & 0.49 & \multirow[b]{2}{*}{0.34} & \multirow[b]{2}{*}{0.74} \\
\hline & $\mathrm{M}$ & $\begin{array}{l}34 \\
52\end{array}$ & $\begin{array}{l}1.30 \\
1.35\end{array}$ & $\begin{array}{l}0.49 \\
0.48\end{array}$ & & \\
\hline Support from & $\mathrm{F}$ & 34 & 1.21 & 0.41 & \multirow{2}{*}{-1.26} & \multirow{2}{*}{0.21} \\
\hline Family & $\mathrm{M}$ & 52 & 1.33 & 0.47 & & \\
\hline Leadership & $\mathrm{F}$ & 34 & 1.85 & 0.36 & \multirow{2}{*}{2.00} & \multirow{2}{*}{0.05} \\
\hline Style & M & 52 & 1.67 & 0.47 & & \\
\hline
\end{tabular}

The table above shows the analysis results that female and male academics have the same study times at their work and home. (Sig. 0,921; 0,145>0.05). So, female and male academics have the same study time distributions at work and home.

\section{Perceptions of Critical Success Factors and Barriers in Career Advancement}

In the literature review a scale is utilized from a similar study for determining critical success factors of academics in career advancement and perceptions related to barriers of career advancement. In this study which was conducted among female public workers in Indonesia, critical success factors are determined as; experience, gender, education, seniority, interpersonal skills, ability in tackling management, commitment \& dedication, support from management \& colleagues, support from family and leadership style. Also barriers to career advancement are determined as; preference for family, limited access to professional training, personality, lack of leadership charisma, lack of confidence, society expectation, gender bias, lack of qualification, insufficient experience, lack of power, no mentoring system, low self esteem, lack of informal network, not being taken seriously, lack of prestigious developmental, assignments [8]. Refering the scale tested in Indonesia, the research question is: "Is there diffirence between female and male academics' perception of critical success factors?"

The research question above is tested with independent sample t-test as shown in Table VI. Accoring to the t-test results, variables which have smaller $p$ values than 0.10 are;

1) Experience

2) Leadership style

TABLE VII: BARRIERS OF CARRIER ADVANCEMENT ACADEMICS ACCORDING TO GENDER

\begin{tabular}{|c|c|c|c|c|c|c|}
\hline Items & Sex & $\begin{array}{c}\mathrm{Fr} \\
\mathrm{e}\end{array}$ & $M$ & $S D$ & $\mathrm{t}$ & $p$ \\
\hline Preference For & $\mathrm{F}$ & 34 & 1.47 & 0.51 & \multirow{2}{*}{-2.58} & \multirow{2}{*}{0.01} \\
\hline Family & M & 52 & 1.75 & 0.44 & & \\
\hline Limited Access to & $\mathrm{F}$ & 34 & 1.68 & 0.48 & \multirow{2}{*}{1.55} & \multirow{2}{*}{0.13} \\
\hline Training & M & 52 & 1.51 & 0.51 & & \\
\hline \multirow{2}{*}{ Personality } & $\mathrm{F}$ & 34 & 1.65 & 0.49 & \multirow{2}{*}{0.89} & \multirow{2}{*}{0.37} \\
\hline & M & 52 & 1.55 & 0.50 & & \\
\hline Lack of Leadership & $\mathrm{F}$ & 34 & 1.94 & 0.24 & \multirow{2}{*}{0.64} & \multirow{2}{*}{0.53} \\
\hline Charisma & M & 52 & 1.90 & 0.30 & & \\
\hline \multirow{2}{*}{ Lack of Confidence } & $\mathrm{F}$ & 34 & 1.50 & 0.51 & \multirow{2}{*}{0.26} & \multirow{2}{*}{0.79} \\
\hline & M & 52 & 1.47 & 0.50 & & \\
\hline \multirow{2}{*}{ Society Expectation } & $\mathrm{F}$ & 34 & 1.88 & 0.33 & \multirow{2}{*}{-0.29} & \multirow{2}{*}{0.78} \\
\hline & M & 52 & 1.90 & 0.30 & & \\
\hline \multirow{2}{*}{ Gender Bias } & $\mathrm{F}$ & 34 & 1.74 & 0.45 & \multirow{2}{*}{-2.17} & \multirow{2}{*}{0.04} \\
\hline & M & 52 & 1.92 & 0.27 & & \\
\hline Lack of & $\mathrm{F}$ & 34 & 1.44 & 0.50 & \multirow{2}{*}{0.63} & \multirow{2}{*}{0.53} \\
\hline Qualification & $\mathrm{M}$ & 52 & 1.37 & 0.49 & & \\
\hline Insufficient & $\mathrm{F}$ & 34 & 1.47 & 0.51 & \multirow{2}{*}{0.00} & \multirow{2}{*}{1.00} \\
\hline Experience & M & 52 & 1.47 & 0.50 & & \\
\hline \multirow{2}{*}{ Lack of Power } & $\mathrm{F}$ & 34 & 1.94 & 0.24 & \multirow{2}{*}{1.23} & \multirow{2}{*}{0.22} \\
\hline & M & 52 & 1.86 & 0.35 & & \\
\hline No Mentoring & $\mathrm{F}$ & 34 & 1.62 & 0.49 & \multirow{2}{*}{0.09} & \multirow{2}{*}{0.93} \\
\hline System & $\mathrm{M}$ & 52 & 1.61 & 0.49 & & \\
\hline \multirow{2}{*}{ Low Self Esteem } & $\mathrm{F}$ & 34 & 1.71 & 0.46 & \multirow{2}{*}{-0.39} & \multirow{2}{*}{0.69} \\
\hline & M & 52 & 1.75 & 0.44 & & \\
\hline Lack of Informal & $\mathrm{F}$ & 34 & 1.65 & 0.49 & & \\
\hline Network & $\mathrm{M}$ & 52 & 1.63 & 0.49 & 0.18 & 0.86 \\
\hline Not Being Taken & $\mathrm{F}$ & 34 & 1.82 & 0.39 & - 024 & 081 \\
\hline Seriously & M & 52 & 1.84 & 0.37 & -0.24 & 0.81 \\
\hline Lack of Prestigious & $\mathrm{F}$ & 34 & 1.88 & 0.33 & & \\
\hline Developmental & M & 52 & 1.86 & 0.35 & 0.26 & 0.80 \\
\hline Assignments & & & & & & \\
\hline
\end{tabular}

Accordingly, perceptions of necessity for success related to such factors are significantly different between female and male academics. Besides, in Konya region male acedemics have higher perception means than female academics in these critical success factors. 
Among all these critical success factors, gender is the variable having lowest mean for both female and male academics. So in other words, gender has the least necessity compared to the other critical success factors.

The research question above is tested with independent sample t-test as shown in Table VII. Accoring to the t-test results, variables which have smaller $p$ values than 0.10 are;

1) Preference For Family

\section{2) Gender Bias}

According to the results of t-tests, perceptions related to barriers of career advancement are significantly different between female and male academics. Besides, in Konya region female acedemics have higher perception means than male academics in these critical success factors.

In a similar study about female public worker in Indonesia, it is found that family comes before career for $60.6 \%$ of women [8]. In this study, preference for family and gender bias factors are found to be different for female and male academics in terms of perceptions related to barriers of career advancement. Also, female academics gives more preference for family than male academics and sees gender as bigger barrier at career advancement.

\section{Academics Responsibility Sharing for Housework}

Marital status' role in women's career development course is closely related to their responsibilities of being more or less [9]. Therefore, married women in working life have priorities like housework, child care, and furthermore perhaps elder care and other responsibilities within family before career advancement.

This research question which is designed for getting an idea about male and femail academics' responsibility sharing for housework, is collected from a previous study with the title "Challenges that female research assistants face in home and worklife." In the study mentioned, it was found that housework, which is idenfied as women work, is handled by female academics, however their husbands and a servant participate in such housework. Husbands of female research assistans mostly takes in hand works like house maintanence, bill/installment payment [10].

TABLE VIII: ACADEMICS' RESPONSIBILITY SHARING FOR HOUSEWORK ACCORDING TO GENDER

\begin{tabular}{|c|c|c|c|c|c|c|}
\hline & \multicolumn{2}{|c|}{ Cooking } & \multicolumn{2}{|c|}{ Laundry } & \multicolumn{2}{|c|}{ Cleaning } \\
\hline & $\mathrm{F}$ & M & $\mathrm{F}$ & M & $\mathrm{F}$ & M \\
\hline \multirow{2}{*}{ Single } & 13 & 0 & 18 & 2 & 6 & 0 \\
\hline & $65.0 \%$ & $0.0 \%$ & $90 \%$ & $5.6 \%$ & $30.0 \%$ & $0.0 \%$ \\
\hline \multirow{2}{*}{$\begin{array}{l}\text { Ownself } \\
\text { \&Others }\end{array}$} & 5 & 11 & 2 & 5 & 7 & 8 \\
\hline & $25.0 \%$ & $\% 30.6$ & $10.0 \%$ & $13.9 \%$ & $35.0 \%$ & $22.2 \%$ \\
\hline \multirow{2}{*}{ Others } & 2 & 25 & 0 & 29 & 7 & 28 \\
\hline & $10.0 \%$ & $69.4 \%$ & $0.0 \%$ & $80.6 \%$ & $35.0 \%$ & $77.8 \%$ \\
\hline Chi-square & \multicolumn{2}{|c|}{0.000} & \multicolumn{2}{|c|}{0.000} & \multicolumn{2}{|c|}{0.000} \\
\hline
\end{tabular}

In this study, interpretations are made according to the significant chi-square test results of research questions about responsibility sharing for housework by female and male academics.

According to the results shown in Table VIII, 65\% majority of female academics cooks and $90 \%$ majority of female academicians do the laundry single-handedly.
Contrarily, in the male academics' cases, cooking for 69.4 percent, laundry for 80.6 percent and cleaning for 77.8 percent are handled by someone other (wife, mother, mother-in-law, servant, etc.)

As it can be understood from Table VIII, responsility sharing of female academics at home is higher than male academics'. Besides they get help from other people specially for cleaning.

\section{E. Stasfaction and Perceptions of Academics in Worklife}

In this part of study, academics' satisfaction and perception levels about a number of cases in worklife are measured. In the survey, the factors in the below table are measured by a likert-type scale in which 1 stands for "strongly agree", 2 stands for "agree", 3 stands for "neutral", 4 stands for "disagree" and 5 stands for "strongly disagree" against the satisfaction and perception statements.

TABLE IX: SATISFACTION OF ACADEMICS IN WORKLIFE ACCORDING TO

\begin{tabular}{lcccccc}
\multicolumn{7}{c}{ GENDER } \\
\hline \hline Factors & Sex & Fre & $M$ & $S D$ & $\mathrm{t}$ & $p$ \\
\hline \multirow{2}{*}{ Position } & $\mathrm{F}$ & 34 & 4.09 & 1.16 & -1.15 & 0.25 \\
& $\mathrm{M}$ & 50 & 4.38 & 1.12 & & \\
Salary & $\mathrm{F}$ & 34 & 3.56 & 1.24 & -0.07 & 0.94 \\
& $\mathrm{M}$ & 50 & 3.58 & 1.36 & & \\
Power & $\mathrm{F}$ & 34 & 3.29 & 1.27 & -2.47 & $\mathbf{0 . 0 2}$ \\
Provided & $\mathrm{M}$ & 50 & 3.92 & 1.05 & & \\
opportunities & $\mathrm{F}$ & 34 & 3.33 & 1.27 & -1.33 & 0.19 \\
Duty sharing & $\mathrm{M}$ & 50 & 3.70 & 1.20 & & \\
& $\mathrm{~F}$ & 34 & 3.27 & 1.28 & -0.45 & 0.65 \\
\hline \hline
\end{tabular}

In Table IX, values belonging to statements indicating satisfaction levels of female and male academics related to worklife are tested via independent sample and one sample t-tests. In the analysis, two-tailed significance values corresponding each hypothesis are comperad with the value of $0.10,90 \%$ confidence interval. For the only variable which has a $\mathrm{p}$ value lesser than 0.10 , a significant difference statement is accepted. Accordingly, female and male academics' satisfaction level of their power are different. Referring the means, it is found that female academics' satisfaction level of power is lower than male academics' in Konya region.

\section{F. Academics' Perceptions of Gender Discrimination in Worklife}

In this part of study, female and male academics' perceptions of gender discrimination in worklife are tried to be identified. One of the research questions prepared in this regard is as follows; is the perception level of gender-related academic preference in their university, different between female and male academics?

Table X shows the analysis result of whether the gender is a determining factor or not, is cases of acceptance to university as academics. According to the tests, both female and male academics have the perception of gender as not being a determining factor for acceptance to their university.

In the survey study, variables shown in the following table measures the approach of participants to the related statement by semantic differentiation scale with the alternatives of "women", "equal" and "men". The research questions 
prepared in this regard is as follows; how are the academics' perceptions of gender discrimination in work place?

TABLE X: ACADEMICS' PERCEPTIONS OF GENDER DISCRIMINATION (I)

\begin{tabular}{lcccccc}
\hline \hline $\begin{array}{l}\text { Gender-related } \\
\text { reasons }\end{array}$ & Fre & Sex & $M$ & $S D$ & $\mathrm{t}$ & $p$ \\
\hline $\begin{array}{l}\text { Male academics is } \\
\text { not preferred }\end{array}$ & 33 & $\mathrm{~F}$ & 1.58 & 0.902 & -0.55 & 0.59 \\
$\begin{array}{l}\text { (due to military } \\
\text { service) }\end{array}$ & 50 & $\mathrm{M}$ & 1.72 & 1.325 & & \\
$\begin{array}{l}\text { Female academics } \\
\text { is not preferred } \\
\text { (due to pregnancy) }\end{array}$ & 33 & $\mathrm{~F}$ & 2.18 & 1.211 & 1.36 & 0.19 \\
\hline \hline
\end{tabular}

TABLE XI: ACADEMICS' PERCEPTIONS OF GENDER-BASED DISCRIMINATION (II)

\begin{tabular}{lccccc}
\hline \hline & Fre & $M$ & $S D$ & $\mathrm{t}$ & $p$ \\
\hline $\begin{array}{l}\text { Which academics } \\
\text { have more } \\
\text { confidence }\end{array}$ & 84 & 1.82 & 0.44 & -3.69 & $\mathbf{0 . 0 0}$ \\
$\begin{array}{l}\text { Which academics are } \\
\text { given more authority }\end{array}$ & 84 & 1.60 & 0.54 & -6.87 & $\mathbf{0 . 0 0}$ \\
$\begin{array}{l}\text { Which academics are } \\
\text { given more }\end{array}$ & 84 & 1.73 & 0.57 & -4.42 & $\mathbf{0 . 0 0}$ \\
$\begin{array}{l}\text { resposibiliy/duty } \\
\text { Which academics are }\end{array}$ & 83 & 1.92 & 0.52 & -1.47 & 0.145 \\
$\begin{array}{l}\text { in favor of rules } \\
\text { which academics in } \\
\text { the same position } \\
\text { gets more salary }\end{array}$ & 81 & 1.94 & 0.24 & -2.29 & $\mathbf{0 . 0 2 4}$ \\
$\begin{array}{l}\text { which academics } \\
\text { organize more } \\
\text { conferences } \\
\text { which academics are } \\
\text { considered more }\end{array}$ & 80 & 1.76 & 0.51 & -4.17 & $\mathbf{0 . 0 0}$ \\
\hline \hline
\end{tabular}

The statements shown in Table XI are tested with one-sample t-test. According to the results of analysis, significance values that correspond each statement are comperad with the value of $0.10,90 \%$ confidence interval. Expect for one variable which has a p value higher than 0.10 , all other hypotheses are accepted. Only rejected hypothesis shows that academics in Konya have a perception that no gender is favored in application of rules.

1) Female and male academics are trusted at different levels in work place.

2) Female and male academics are given different powers in work place

3) Female and male academics are given different levels of responsibility/duty in work place

4) Female and male academics in same position gets different amounts of salary in work place

5) Female and male academics organize different numbers of conferences in work place

6) Female and male academics are considered at different levels in work place

As for the hypothesis above having significance statistics lower than 0.10, all have been accepted. Another result of the analysis which can also be seen in Table XI shows that these values are higher for male academics.

Accordingly, male academics in Konya are trusted more, are given power more, are given responsibility/duty more, gets more salary, organize more conferences and are considered more compared to female academics. From the point of this table, academics in Konya have perception of gender-based discrimination.

\section{CONCLUSION AND RECOMMENDATIONS}

In this study for the purpose of determining academics' negative and positive perceptions of gender factor in career advancement, a survey with a sample of total 86 academics was conducted among 2 public and 2 foundation universities in Konya province of Turkey. With the analysis the satisfaction levels of academics about the worklife and their perception of gender-based discrimination are identified.

The proposition that male academics publish more research studies than female academics have been accepted.

It is defined that male and female academics have equal distribution of working time at home and in the workplace.

According to gender, male academics have higher perception means than female academics in critical success factors of experience and leadership style.

One of findings of this research that attracts attention is the least necessity perception of gender among all critical success factors for both female and male academics. Thus it can be concluded as academics in Konya do not perceive gender as a factor necessary for success.

Preference for family and gender bias factors are found to be different between female and male academics working in Konya in terms of perceptions related to barriers of career advancement. Besides, giving more preference for family and gender bias are perceived as bigger barrier at career advancement by female academics when compared to male academics.

Male academics in Konya are more satisfied with the powers they have than female academics. Both female and male academics believe gender as not a determining factor for academics' recruitment by university.

Also, the results showed that in the perception of both female and male academics, no gender is favored in terms of application of rules at their university. On the contrary, academics in Konya perceive male academics as being trusted more, given power more, given responsibility/duty more, getting more salary, organizing more conferences and being considered more than female academics. Therefore, it can be said that academics in Konya have gender-based discrimination perception.

The gender discrimination in the workplace reduces employee productivity and affects performance poorly [11]. Hence it can be said that having gender-based discrimination perception of academics affect their academic life negatively. Where the application of rules on equal terms for female and male academics indicates conformity to principles of social justice, the gender-based discrimination between academics are based on different applications. In this study, more level of given trust, power, responsibility and duty of male academics reinforces the gender based discrimination accusations.

For the purpose of gender factor as not affecting career advancement negatively, these perceptions have to be eliminated. Thus, the performance of female academics and consequently productivity is likely to increase. 


\section{REFERENCES}

[1] G. Marshall, Sosyoloji Sözlüğ̈̈, Bilim ve Sanat Yayınları, Ankara, 1999, p. 101

[2] Z. Dökmen, Toplumsal Cinsiyet, Sistem Yayıncılık, İstanbul, p. 4.

[3] D. Sav, "Bireysel kariyer planlamada etkili olan faktörler ve üniversitelerin etkisi üzerine bir araştirma," M.S. thesis, Dept. Bussiness Adm., Süleyman Demirel Univ., Isparta, 2008.

[4] E. Yilmaz and G. Özdemir, "Türkiye'de kadın akademisyen ve araştirmacilarin karşilaştiklari sorunlar ve tarima bakiş açilari," International Journal of all Subjects of Agriculture, 2012, vol. 9, pp. 50-56.

[5] Yükseköğretim bilgi sistemi. [Online]. Available: https://istatistik.yok.gov.tr/

[6] N. Karasar, Bilimsel Araştırma Yöntemi, Nobel Yayın, $24^{\text {th }}$ ed. Turkey: Ankara, p. 77.

[7] R. Altunışık, Ş. Özdemir, and Ö. Torlak, Pazarlama Illkeleri ve Yönetimi, Beta Yayın, İstanbul, 2004, p. 187.

[8] I. Azmi, S. İsmail, and A. Basir, "Women career advancement in public service: a study in Indonesia," in Proc. 8th International Strategic Management Conference on Procedia - Social and Behavioral Science, pp. 298-306, Malaysia, 2012.

[9] T. Kagider, "Türkiye'de toplumsal cinsiyet eşitsizliği: Sorunlar, öncelikler ve çözüm önerileri,” Kadın-Erkek Eşitliğine Doğru Yürüyüş: Eğitim, Çalışma Yaşamı ve Siyaset" Raporunun Güncellemesi, Graphis Matbaa, p. 157, İstanbul, 2008.
[10] Ş. Ergöl, G. Koç, K. Eroğlu, and L. Taşkın, “Türkiye'de kadın araştirma görevlilerinin ev ve iş yaşamlarinda karşilaştiklari GüçlüKLER,” Yüksekögretim ve Bilim Dergisi, vol. 1, pp. 43-49.

[11] A. Hameed and A. Waheed, "Gender discrimination and its effect on employeeper formance/ productivity," International Journal of Humanities and Social Science, vol. 1, pp. 170-176, Los Angeles, 2011.

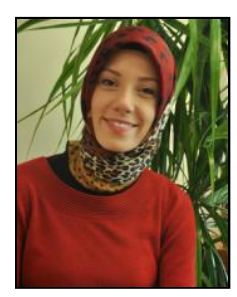

Dilara Ustabaşı Gündüz was born in Aydın, Turkey, in 1988. She finished her bachelor's degree in socia work from Sakarya University, Sakarya, Turkey in 2011 and her master's degree in social work from Yalova University. She is currently a $\mathrm{PhD}$ candidate in social politics at Yıldırım Beyazıt University, Ankara, Turkey.

After graduation she worked as a social worker at Kocaeli Metropolitan Municipality, Directorate of Social Services, the Social Welfare Department for one year. At present she is a research assistant at the Department of Social Work, KTO Karatay University, Konya, Turkey from 2012. Her research interests are social work practices in local government, psychosocial compliance and educational problems, social assistance applications, gender, community mental health, symbiotic culture and integration. 